\title{
Poultry litter and fresh mulch of Elephant grass improve the organic potato production ${ }^{1}$
}

\author{
Renato Yagi ${ }^{2}$, Nilceu Ricetti Xavier de Nazareno ${ }^{3}$, Jackson Kawakami ${ }^{4}$
}

\begin{abstract}
The organic production system for potato is usually limited by the occurrence of diseases and nutrient shortage. In these cases, fresh grass mulch and organic fertilization can interact in the foliar late blight infestation and increase the yield and quality of marketable potato tubers, in the organic production system. Aiming to validate this hypothesis, four poultry litter doses $\left(0 \mathrm{Mg} \mathrm{ha}^{-1}, 10 \mathrm{Mg} \mathrm{ha}^{-1}, 20 \mathrm{Mg} \mathrm{ha}^{-1}\right.$ and $\left.30 \mathrm{Mg} \mathrm{ha}^{-1}\right)$, which were incorporated into the soil at the pre-planting stage of organic grown potato combined with the presence and absence of fresh mulch $\left(60 \mathrm{Mg} \mathrm{ha}^{-1}\right)$ composed of chopped Elephant grass, were tested. The incorporation of poultry litter into the soil at the pre-planting of potato or the use of fresh grass mulch after the potato hilling inhibits the late blight infestation on leaves, in the organic system. The application of fresh grass mulch after the hilling operation enhances the effect of organic fertilization at the pre-planting of potatoes. The pre-planting application of poultry litter increases the yield and decreases the specific gravities of marketable potato tubers in association with fresh grass mulch. The use of poultry litter at pre-planting and fresh grass mulch improve the sustainable potato cropping in the organic production system.
\end{abstract}

KEYWORDS: Solanum tuberosum, Phytophthora infestans, chicken manure, organic agriculture.

\section{INTRODUCTION}

The potato (Solanum tuberosum L.) production will remain important for future food security, especially in developing countries, and crop management (e.g., $\mathrm{N}$ input) will probably contribute more to increase yields than the cultivar improvement itself (Kleinwechter et al. 2016).

The production in organic potato systems is lower than in conventional ones. According to Palmer et al. (2013), in a long term experiment

\section{RESUMO}

Cama de aviário e cobertura morta de capim-elefante melhoram a produção de batata orgânica

O sistema orgânico de produção de batata é geralmente limitado pela infestação de doenças e pela escassez de nutrientes. Nesses casos, mulch de capim fresco e adubação orgânica podem interagir na infestação por requeima foliar e na produtividade e qualidade de tubérculos comerciais de batata, em sistema orgânico de produção. Visando validar essa hipótese, foram testadas quatro doses de cama de aviário ( $0 \mathrm{Mg} \mathrm{ha}^{-1}, 10 \mathrm{Mg} \mathrm{ha}^{-1}, 20 \mathrm{Mg} \mathrm{ha}^{-1}$ e $\left.30 \mathrm{Mg} \mathrm{ha}^{-1}\right)$, incorporadas ao solo no pré-plantio de batata orgânica, combinadas com a presença e ausência de mulch $\left(60 \mathrm{Mg} \mathrm{ha}^{-1}\right)$, formado por capim Elefante fresco picado. A incorporação de cama de aviário no pré-plantio de batata ou o uso de mulch de capim fresco antes da amontoa inibe a epidemia de requeima foliar em sistema orgânico. A aplicação de mulch de capim fresco após a operação de amontoa potencializa o efeito da adubação orgânica em pré-plantio de batata. Doses de cama de aviário em pré-plantio aumentam a produtividade e diminuem o peso específico de tubérculos comerciais de batata, quando associadas ao mulch de capim fresco. O uso de cama de aviário no pré-plantio e de mulch de capim fresco melhoram o cultivo sustentável de batata no sistema de produção orgânica.

PALAVRAS-CHAVE: Solanum tuberosum, Phytophthora infestans, esterco de galinha, agricultura orgânica.

comparing organic and conventional fertilization, pre-planting crops and organic and conventional pest and disease control systems, the efficient $\mathrm{N}$ management has a greater influence on tuber yields in organic systems, if compared to conventional ones, using agrochemicals to control late blight [Phytophthora infestans (Mont.) de Bary] and other pathogens. Organic potato cultivars, in addition to presenting resistance features, should have a rapid and early canopy development, supporting high $\mathrm{N}$ doses, in order to delay the late blight infection and, 
consequently, result in higher tuber yields (TiemensHulscher et al. 2014).

Moderate $\mathrm{N}$ use is a recommended crop practice to delay the late blight development, because the excess of $\mathrm{N}$ fertilization can lead to increases in the disease severity, requiring more fungicides to prevent losses (Arora et al. 2014). With similar P and $\mathrm{K}$ tuber contents in organic fertilization, when compared to the conventional fertilization of potato, but with a $30 \%$ lower $\mathrm{N}$ tuber concentration, there is an evidence that the $\mathrm{N}$ availability is the main reason to explain the lower tuber yields in organic cropping (Palmer et al. 2013). Regarding the $\mathrm{N}$ nutrition of potato plants, the ammonium $\left(\mathrm{NH}_{4}^{+}-\mathrm{N}\right)$ and nitrate $\left(\mathrm{NO}_{3}{ }^{-} \mathrm{N}\right)$ combination is more important for the $\mathrm{N}$ uptake and tuber yield increase than the use of these forms alone (Cao \& Tibbitts 1993, Serio et al. 2004). $\mathrm{NO}_{3}-\mathrm{N}$ inputs stimulate the stolon branching and growth, whereas $\mathrm{NH}_{4}^{+}-\mathrm{N}$ stimulates the tuber swelling (Osaki et al. 1995). However, the $\mathrm{NO}_{3}{ }^{-}-\mathrm{N}$ efficiency is greater for potato tuber by means of improving the shoot growth, what will subsequently provide more assimilates after the tuber initiation stage (Gao et al. 2014).

Poultry litter is an economical and technical alternative to the use of inorganic fertilizers, providing sufficient amounts of $\mathrm{N}$, but adding $\mathrm{P}$ and $\mathrm{K}$ contents higher than needed by organic potato crops (Fioreze \& Ceretta 2006). Poultry litter fertilization shows positive trends in improving marketable tuber yields, with reductions in small tubers yields and in specific gravities (Rees et al. 2014). Poultry litter is largely used by small growers in the southern region of Brazil, and its application provides $\mathrm{NH}_{4}^{+}-\mathrm{N}$ amounts proportionally to the applied doses, with more rapid conversion into $\mathrm{NO}_{3}^{-}-\mathrm{N}$ when incorporated, rather than when applied on the soil surface (Rogeri et al. 2015). The soil incorporation of fresh manure in the spring is a recommended practice to supply $\mathrm{N}$ in organic farming, synchronizing the crop demands and $\mathrm{N}$ cycling in the soil (Berry et al. 2002).

Organic mulch on potato crop is a technique that can reduce the erosion and loss of soil organic matter, $\mathrm{NO}_{3}^{-}-\mathrm{N}$ and available $\mathrm{P}, \mathrm{K}, \mathrm{Ca}$ and $\mathrm{Mg}$ by runoff, increasing the total and marketable tubers yields (Rees et al. 2002). Mulching with organic residues decreases the soil thermal amplitude and soil water evaporation, thus increasing the $\mathrm{N}$ uptake and the efficiency of the $\mathrm{N}$ fertilization to enhance higher potato tuber yields (Singh et al. 2015). Besides this buffer effect on the soil hydrothermal conditions, organic mulching also adds plant nutrients to the soil after decomposition, but also can immobilize $\mathrm{N}$ by microorganisms (Kader et al. 2017) and, therefore, reduces the $\mathrm{NO}_{3}^{-}-\mathrm{N}$ leaching to the soil profile (Döring et al. 2005).

The hypothesis in the present study is that the fertilization with poultry litter incorporated into the soil at pre-planting may interact with fresh mulch and decrease the foliar late blight severity, with an increase of tuber yields. Thus, this study aimed to evaluate the effect of the interaction between fertilization with pre-planting doses of poultry litter and the use of fresh mulch after hilling on the severity of foliar late blight and yields and specific gravity of potato tubers cultivated in the organic system.

\section{MATERIAL AND METHODS}

The field study was conducted at the Instituto Agronômico do Paraná experimental station, in

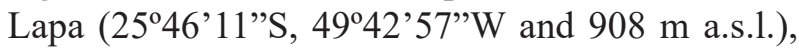
Paraná state, southern Brazil. The local climate is classified as Cfb, according to the Köppen's climate classification, with mild summer and evenly distributed rainfall, no dry season and mean temperature of the warmest month inferior to $22^{\circ} \mathrm{C}$. The precipitation volume varies from $1,100 \mathrm{~mm}$ to $2,000 \mathrm{~mm}$, with the occurrence of severe and frequent frosts in the coldest months. The cumulative rainfall data and average maximum and minimum temperatures during the experimental period (from October 2017 to February 2018) were recorded by a weather station located $300 \mathrm{~m}$ away from the experimental plots (Figure 1).

The soil of the experimental area was classified as a medium texture Haplic Cambisol (Embrapa 2014), equivalent to an Inceptisol (USA 2014). Chemical (Pavan et al. 1992) and physical (Embrapa 1997) soil tests were performed and presented the following results (0-0.2 $\mathrm{m}$ layer): $\mathrm{pH}$ $\left(\mathrm{CaCl}_{2}\right)=5.1 ; \mathrm{C}($ Walkley \& Black $)=24.5 \mathrm{~g} \mathrm{dm}^{-3}$; $\mathrm{P}($ Mehlich 1$)=4.6 \mathrm{mg} \mathrm{dm}^{-3} ; \mathrm{K}($ Mehlich 1$)=$ $0.61 \mathrm{cmol}_{\mathrm{c}} \mathrm{dm}^{-3} ; \mathrm{Ca}(\mathrm{KCl})=5.72 \mathrm{cmol}_{\mathrm{c}} \mathrm{dm}^{-3}$; $\mathrm{Mg}(\mathrm{KCl})=3.30 \mathrm{cmol}_{\mathrm{c}} \mathrm{dm}^{-3}$; saturation base index $(\mathrm{V} \%)=63.4 \%$; sand $=478 \mathrm{~g} \mathrm{~kg}^{-1}$; clay $=$ $319 \mathrm{~g} \mathrm{~kg}^{-1}$; and silt $=203 \mathrm{~g} \mathrm{~kg}^{-1}$. Considering the soil chemical attributes, the soil area was classified as very high for $\mathrm{K}$, low for $\mathrm{P}$, with a high $\mathrm{pH}$, high $\mathrm{V} \%$ and very high organic C (Nepar-SBCS 2017). 


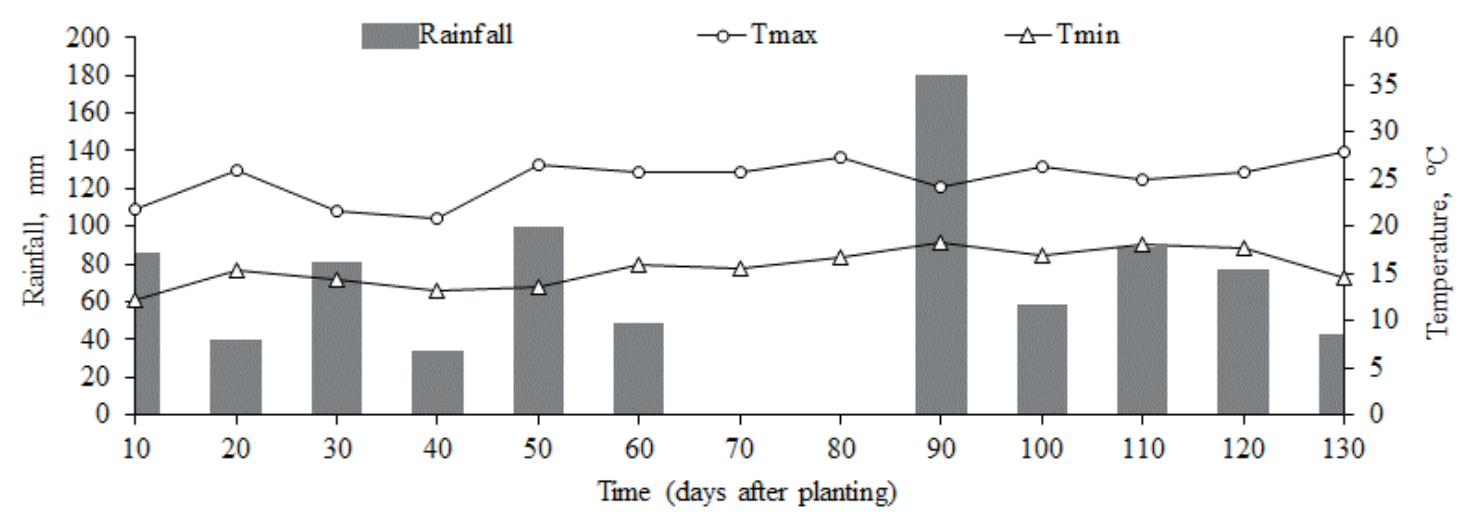

Figure 1. Rainfall and maximum (Tmax) and minimum (Tmin) temperatures during the experimental period (Lapa, Paraná state, Brazil, October 2017 to February 2018).

Four poultry litter doses $\left(0 \mathrm{Mg} \mathrm{ha}^{-1}, 10 \mathrm{Mg} \mathrm{ha}^{-1}\right.$, $20 \mathrm{Mg} \mathrm{ha}^{-1}$ and $30 \mathrm{Mg} \mathrm{ha}^{-1}$ ) were combined with and without mulching, in a $4 \times 2$ factorial scheme, in a randomized block design with four replicates. Each poultry litter dose was manually distributed on the respective plots. The plots were subdivided into four quadrants and the poultry litter dose was uniformly distributed on a mass basis in each quadrant.

After the distribution of all treatments, the soil was ploughed and harrowed at 15 days before planting. The poultry litter water content was determined by the difference between the natural and oven dried $\left(65^{\circ} \mathrm{C}\right.$ to constant mass) sample weight and transformed into percentage. Poultry litter samples were prepared by digestion with sulfuric acid, with a subsequent determination of ammonium-N by UV-visible spectrophotometry with blue indophenol, and by digestion with hydrochloric acid and determinations of $\mathrm{P}, \mathrm{K}, \mathrm{Ca}, \mathrm{Mg}, \mathrm{Cu}, \mathrm{Zn}, \mathrm{B}$ and $\mathrm{Mn}$ by inductively coupled plasma-atomic emission spectrometry. The chemical analysis (Tedesco et al. 1995) of the poultry litter (17.8\% of humidity) revealed $178.9 \mathrm{~g} \mathrm{~kg}^{-1}$ of $\mathrm{C} ; 14.2 \mathrm{~g} \mathrm{~kg}^{-1}$ of N; $26.7 \mathrm{~g} \mathrm{~kg}^{-1}$ of P; $31.2 \mathrm{~g} \mathrm{~kg}^{-1}$ of K ; $118.8 \mathrm{~g} \mathrm{~kg}^{-1}$ of Ca; $51.0 \mathrm{~g} \mathrm{~kg}^{-1}$ of Mg; $6.4 \mathrm{~g} \mathrm{~kg}^{-1}$ of S; $499 \mathrm{mg} \mathrm{kg}^{-1}$ of Cu; $5,059 \mathrm{mg} \mathrm{kg}^{-1}$ of Fe; $455 \mathrm{mg} \mathrm{kg}^{-1}$ of $\mathrm{Zn} ; 27 \mathrm{mg} \mathrm{kg}^{-1}$ of B; and $774 \mathrm{mg} \mathrm{kg}^{-1}$ of $\mathrm{Mn}$.

Each plot was composed of four rows spaced $0.80 \mathrm{~m}$, with $5 \mathrm{~m}$ in length. In each planting row, 17 potato tuber seeds of the IPR Cris cultivar were planted (Oct. 10, 2017), with about $0.25 \mathrm{~m}$ in depth and $0.30 \mathrm{~m}$ apart. After around a month (Nov. 09, 2017), hilling was performed and then fresh mowed Elephant grass residue [Panicum maximum (Jacq.)], at a dose of $60 \mathrm{Mg} \mathrm{ha}^{-1}$ (84.8\% of humidity), was applied over the formed ridges, in the respective plots, with mulch. The grass distribution was performed on a mass basis onto the plot quadrants, similarly to the distribution of the poultry litter. The results for the chemical analysis (Tedesco et al. 1995) of the grass mulching residue were (dry base): $421.5 \mathrm{~g} \mathrm{~kg}^{-1}$ of C; $12.4 \mathrm{~g} \mathrm{~kg}^{-1}$ of N; $4.3 \mathrm{~g} \mathrm{~kg}^{-1}$ of P; $46.3 \mathrm{~g} \mathrm{~kg}^{-1}$ of K ; $4.6 \mathrm{~g} \mathrm{~kg}^{-1}$ of Ca; $3.1 \mathrm{~g} \mathrm{~kg}^{-1}$ of Mg; $21.3 \mathrm{mg} \mathrm{kg}^{-1}$ of Cu; $522.0 \mathrm{mg} \mathrm{kg}^{-1}$ of Fe; $29.6 \mathrm{mg} \mathrm{kg}^{-1}$ of Zn; $3.7 \mathrm{mg} \mathrm{kg}^{-1}$ of $\mathrm{B}$; and $123.4 \mathrm{mg} \mathrm{kg}^{-1}$ of Mn.

The experiment was conducted in an organic system, with mechanical weed control and inputs application authorized by the Brazilian regulation for organic products. A commercial mixture composed by $100 \mathrm{~g}$ of calcium oxide and $100 \mathrm{~g}$ of copper sulphate in $10 \mathrm{~L}$ of water (Bordeaux mixture) was applied twice a week, at the concentration of $1 \%$. A copper-based solution was applied in a similar way to that used by Brazilian organic family farmers. Similarly, a tobacco extract produced from rope tobacco $(100 \mathrm{~g})$ in $1 \mathrm{~L}$ of $70 \%$ alcohol, applied at $1 \%$ with solid soap $(10 \mathrm{~g})$ and $20 \mathrm{~L}$ of water, was used to control Diabrotica speciosa (Germar), when imminent pest symptoms began to appear.

The leaf blight symptoms were visually assessed every seven days, up to 101 days after planting, when the epidemic was covering almost the entire plot area. The disease diagram, key 3.1.1, proposed by James (1971) was used as a visual reference of the disease severity. Evaluations of leaf blight symptoms were obtained from all plants in each one of the plot quadrants.

The harvest was performed on Feb. 8, 2018, at 121 days after planting, considering the two central rows in each plot and leaving the outer rows as borders. The tubers were classified and weighed as 
marketable ( $>45 \mathrm{~mm}$ of diameter) and unmarketable ( $<45 \mathrm{~mm}$ of diameter), with the aid of a coarse mesh sieve, on an inclined grading table. The tuber yields of both classes were summed to obtain the total tuber yields. From each plot, a random sample of ten marketable tubers was weighed in both the air (Wa) and water (Ww) to calculate the tuber specific gravity $(\mathrm{SG})$ by: $\mathrm{SG}=\mathrm{Wa} /(\mathrm{Wa}-\mathrm{Ww})$.

The data were submitted to analysis of variance by the $\mathrm{F}$ test at $5 \%$ of significance. The quantitative factors (poultry litter doses) were deployed in plots with and without mulching through polynomial regression analysis at $5 \%$ and $1 \%$ of probability. The difference between the treatments without and with mulching, in the case of significant interactions, was evaluated by the Tukey test $(\mathrm{p}<0.05)$. Pearson's linear correlations were investigated among the dependent variables of interest. All statistical analyses were performed using the AgroEstat software (Barbosa \& Maldonado Júnior 2015).

\section{RESULTS AND DISCUSSION}

Even with weekly $\mathrm{Cu}$ applications up to the end of the cycle, the plots without fresh Elephant grass mulch and poultry litter at the pre-planting stage presented an average late blight severity of up to $80 \%$ (Figure 2). According to Finckh et al. (2006), the late blight control using Cu-based sprays is limited and inefficient, due to its action, in comparison to systemic fungicides. These same authors reported that the soil fertility, crop nutrient status and the ability of a given potato cultivar to make use of organic sources efficiently are very important factors to build strategies against late blight in the organic production. For the IPR Cris potato, a moderately resistant cultivar selected to be used in organic production systems in southern Brazil (Nazareno et al. 2015), both mulching (Figure 2a) and poultry litter doses (Figure 2b) decreased $(\mathrm{p}<0.05)$ the leaf area infested by late blight without an interactive effect $(p<0.05)$ between these factors (Table 1).

The presence of fresh grass mulch with Elephant grass reduced the late blight severity by $19.9 \%$, from $79.6 \%$ to $63.8 \%$ for foliar severity (Figure 2a), confirming findings in Europe and in the USA (Nyankanga et al. 2008, Dvorák et al. 2010). A decrease in the late blight severity of $29.6 \%$ (84.1 \% to $59.2 \%)$ was also observed with

Table 1. F-test values ${ }^{1}$ in the analysis of variance for late blight severity (LBS), non-marketable tubers (NMT), marketable tubers (MT), total tubers (TT) yields and specific gravity of marketable tubers (SG), as a function of poultry litter doses and grass mulching with Elephant grass.

\begin{tabular}{llllll}
\hline \multicolumn{1}{c}{ Sources of variation } & LBS & NMT & MT & TT & SG \\
\hline Poultry litter (PL) & $7.7^{*}$ & $2.1^{\mathrm{ns}}$ & $7.5^{*}$ & $4.2^{\mathrm{ns}}$ & $2.8^{\mathrm{ns}}$ \\
Mulching (M) & $3.7^{*}$ & $0.6^{\mathrm{ns}}$ & $4.6^{*}$ & $7.3^{*}$ & $1.4^{\mathrm{ns}}$ \\
Interaction PL x M & $0.5^{\mathrm{ns}}$ & $3.1^{*}$ & $2.7^{*}$ & $3.2^{*}$ & $3.0^{*}$ \\
\hline
\end{tabular}

ns and *: non-significant and significant values at $5 \%$ of probability, respectively.
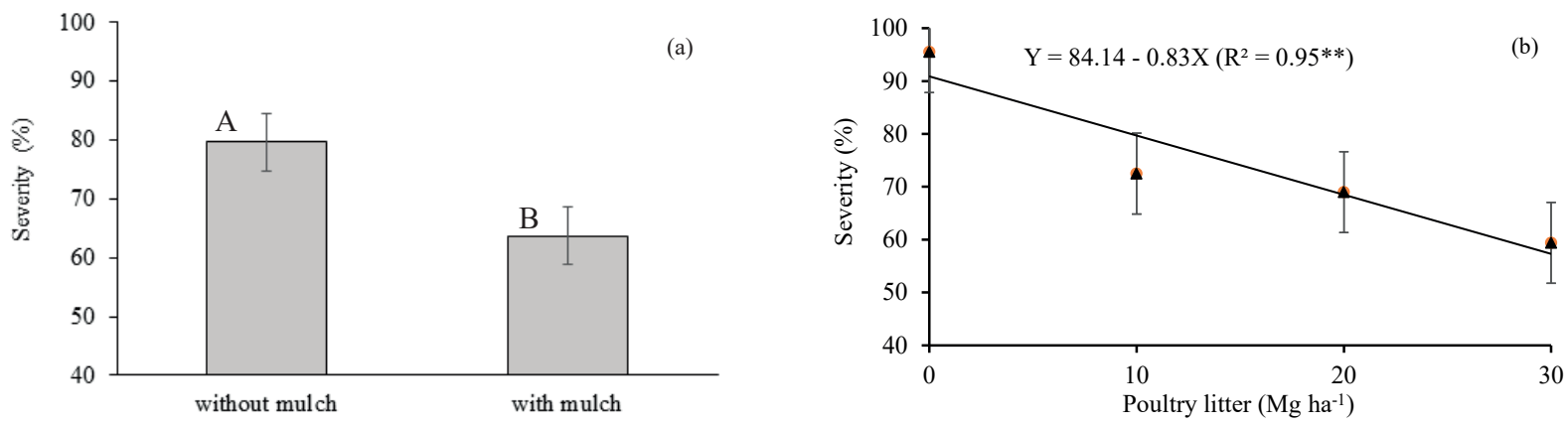

Figure 2. Means of late blight (Phytophthora infestans) severity (Y) on leaves at 101 days after planting, as a function of the absence or presence of Elephant grass mulch (a) or poultry litter doses (X) incorporated into the soil in the pre-planting stage of organic potato crop (b). Vertical bars indicate the respective mean standard errors; means with distinct capital letters in (a) are statistically different $(\mathrm{p}<0.05)$ by the Tukey test; and $* *$ is a significant value at $1 \%$ of probability. 
the application of the maximum poultry litter dose incorporated into the soil at the pre-planting stage (Figure 2b). By means of the linear regression, it was observed that $63.8 \%$ of the late blight severity was obtained with fresh grass mulch with the equivalent to $24.5 \mathrm{Mg} \mathrm{ha}^{-1}$ of poultry litter incorporated into the soil at pre-planting.

Straw mulch may lead to lower temperatures on the soil surface and on the air, with a cooler nocturnal microclimate, and may also prevent the rain splash dispersal of oospores, what probably led to a reduction $(\mathrm{p}<0.05)$ of the late blight infestation in four experiments and a reduction trend in 13 of a total of 15 organic system experiments (Döring et al. 2006). Fresh and chopped Elephant grass residues with $84.8 \%$ of humidity, as mulch, would have altered the microclimatic and epidemiologic conditions to the $P$. infestans propagation. But its high C:N ratio (34:1) also may have favored the multiplication and action of beneficial microorganisms from the organic compost, which may produce antibiotics and inhibit the development of phytopathogens (Islam et al. 2013), as a decreasing of late blight susceptibility with an excess of $\mathrm{N}$ (Ros et al. 2008).

There was a significant decrease $(\mathrm{p}<0.05)$ of $43.2 \%$ of leaves per plant infected by $P$. infestans with poultry litter application in the organic system of potato production. For this, Islam et al. (2013) compiled the following justifications: i) nutrient competition between the plant pathogens and beneficial microbes; ii) antibiotic compounds produced by these beneficial microorganisms; iii) parasitism and predation by beneficial microorganisms; iv) induction of systemic resistance in plants by microorganisms from manure or soil. Studying interactions of late blight susceptibility as a function of $\mathrm{N}$ availability to potato cultivars, Ros et al. (2008) observed that a high N availability significantly increased the susceptibility of three of the four potato cultivars, but, on the other hand, a better $\mathrm{N}$ nutrition induced more defense/ stress-related genes.

With freshly mowed Elephant grass mulch, the non-marketable tubers $(\mathrm{d}<45 \mathrm{~mm})$ increased as a quadratic response $\left(\mathrm{R}^{2}=0.81^{* *}\right)$ with the poultry litter dose of $17.7 \mathrm{Mg} \mathrm{ha}^{-1}$, resulting in a maximum of $8.2 \mathrm{Mg} \mathrm{ha}^{-1}$ of tubers $(306.9 \%$ increase); whereas, without mulch, the poultry litter doses would not affect this result (Figure 3a). These results contradict those obtained by Rees et al. (2014), who observed that the incorporation of poultry litter at the pre-planting stage, during three years, decreased $(p<0.05)$ the average yield of smaller tubers. Associated to the poultry litter application, non-marketable tubers yields were similar $(p>0.05)$ between the treatments with and without mulching; but, in the control treatment without poultry litter fertilization, the presence of fresh grass mulch
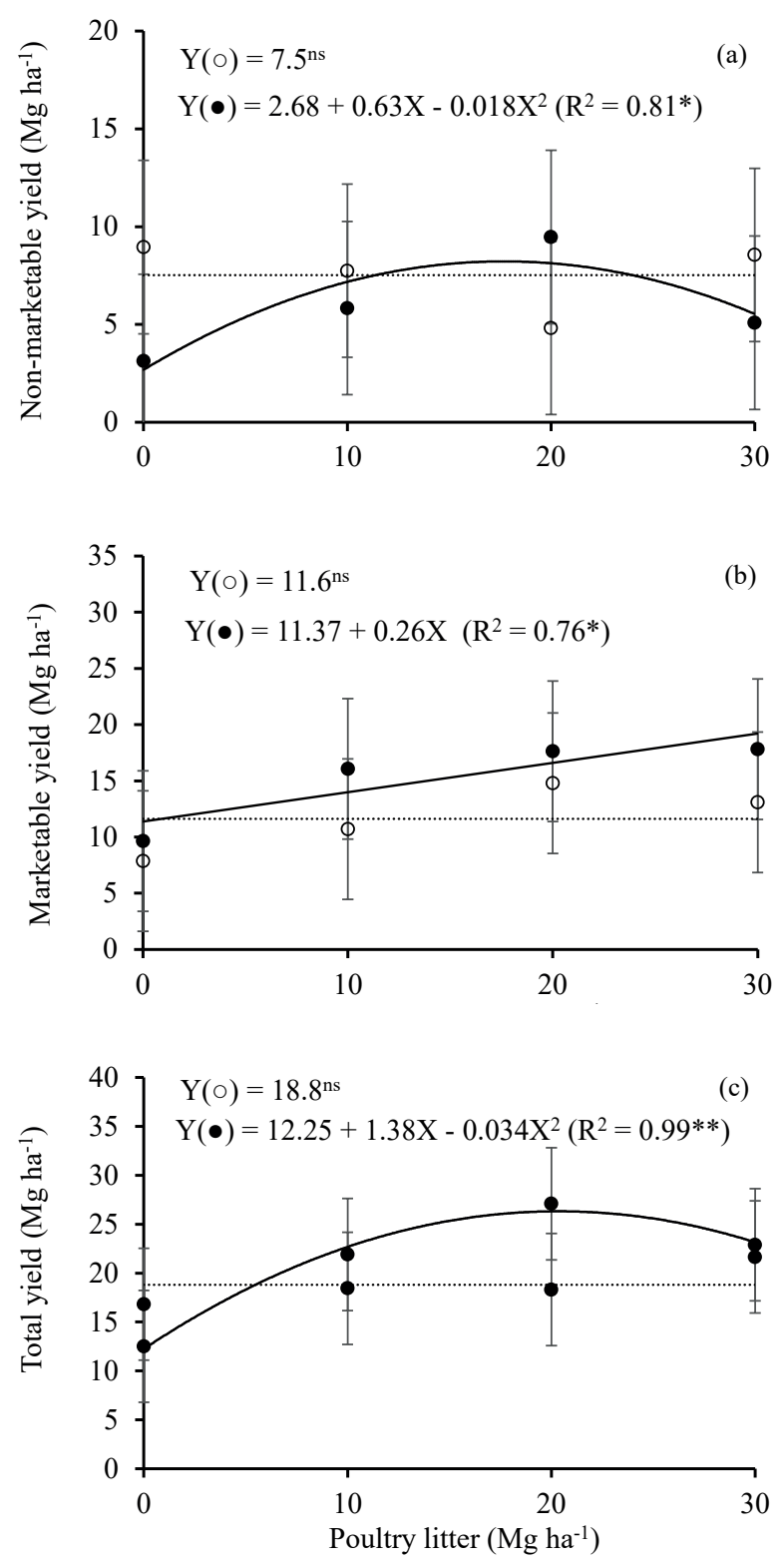

Figure 3. Non-marketable (a), marketable (b) and total tubers (c) yields (Y), as a function of treatments without (O) or with $(\bullet)$ Elephant grass mulching combined with poultry litter doses $(\mathrm{X})$ incorporated into the soil, at the pre-planting of organic potato crop. Vertical bars are the mean standard errors. ${ }^{\text {ns }}, *$ and $* *$ : non-significant $(\mathrm{p}>0.05)$ and significant values at $5 \%$ or $1 \%$ of probability, respectively. 
decreased by $5.8 \mathrm{Mg} \mathrm{ha}^{-1}(65.1 \%)$ the yield of the non-marketable tubers, in comparison to plots without mulching.

In mulching made with $\mathrm{C}$-rich materials, such as straw or stalks, microorganisms can use the soil $\mathrm{N}$ to decompose these materials, making them unavailable to plants (Kader et al. 2017). In fact, it was observed that, at the beginning of the vegetative phase, in plots with mulching, plants developed more slowly, if compared to plots without mulching, indicating that there could be less $\mathrm{N}$ availability for them (data not shown). Marketable tubers also increased linearly $\left(\mathrm{R}^{2}=\right.$ $\left.0.76^{*}\right)$ with the poultry litter doses in the fresh grass mulch treatment, but did not vary in plots without mulching (Figure 2b). A maximum increase of $19.2 \mathrm{Mg} \mathrm{ha}^{-1}\left(7.8 \mathrm{Mg} \mathrm{ha}^{-1} ; 68.9 \%\right)$ was obtained with $30 \mathrm{Mg} \mathrm{ha}^{-1}$ of poultry litter with Elephant grass mulch at the pre-planting stage, being $23.4 \%$ $\left(3.4 \mathrm{Mg} \mathrm{ha}^{-1}\right)$ higher $(\mathrm{p}<0.05)$ than the same poultry litter dose without mulching.

The fresh Elephant grass mulching and maximum poultry litter dose of $30 \mathrm{Mg} \mathrm{ha}^{-1}$ provided $463 \mathrm{~kg} \mathrm{ha}^{-1}$ of N, $304 \mathrm{~kg} \mathrm{ha}^{-1}$ of $\mathrm{P}_{2} \mathrm{O}_{5}$ and $988 \mathrm{~kg} \mathrm{ha}^{-1}$ of $\mathrm{K}_{2} \mathrm{O}$, respectively $32 \%, 6 \%$ and $55 \%$ more $\mathrm{N}, \mathrm{P}$ and $\mathrm{K}$ than the same dose of this manure alone. The total tuber yields increased as a quadratic response $\left(\mathrm{R}=0.99^{* *}\right)$ only in the plots with fresh grass mulch, reaching $26.3 \mathrm{Mg} \mathrm{ha}^{-1}$ with $20.3 \mathrm{Mg} \mathrm{ha}^{-1}$ of poultry litter (Figure 3c). Moreover, with $20 \mathrm{Mg} \mathrm{ha}^{-1}$ of poultry litter, there was a $33.8 \%\left(6.9 \mathrm{Mg} \mathrm{ha}^{-1}\right)$ increase $(p<0.05)$ in the total tuber yield with fresh grass mulch, in comparison to plots without mulching. Elephant grass residues resulted in a higher soil surface persistence and lower nutrient release (Nascente et al. 2014). Possibly, the effect of the interaction between the use of mulch and poultry litter application could be more related to the physical protection of the soil, since there was no difference $(\mathrm{p}<0.05)$ between the plots with and without fresh grass mulch on marketable tuber yields, in plots not fertilized with poultry litter (Figure 2b).

The soil incorporation of poultry litter favors the quick conversion of $\mathrm{NH}_{4}^{+}-\mathrm{N}^{+} \mathrm{NO}_{3}^{-}-\mathrm{N}$, due to the greater contact with soil nitrifying microorganisms, but not all the water soluble $\mathrm{N}$ in the poultry litter is mineralized and/or nitrified, due to possible denitrification losses and temporary retention by microbial immobilization (Rogeri et al. 2015). On a sandy soil under $719 \mathrm{~mm}$ of accumulated rainfall, at six months after organic fertilizing at the preplanting stage (Figure 1), the fresh Elephant grass mulch probably preserved the $\mathrm{NH}_{4}{ }^{+}-\mathrm{N}$ and $\mathrm{NO}_{3}{ }^{-}-\mathrm{N}$ and other nutrients, providing an increase in the marketable tuber yields. On the other hand, the absence of $60 \mathrm{Mg} \mathrm{ha}^{-1}$ of fresh Elephant grass mulch, equivalent to about $9 \mathrm{Mg} \mathrm{ha}^{-1}$ of dry matter, applied over the potato planting rows under torrential rainfall (169 $\mathrm{mm})$, at a tuber bulking stage 90 days after planting (Figure 1), probably favored the nutrient loss by leaching and reduced the marketable tubers yields.

In two experiments on sandy soils $\left(557 \mathrm{~g} \mathrm{~kg}^{-1}\right.$ and $590 \mathrm{~g} \mathrm{~kg}^{-1}$ of sand) in the organic system, Lynch et al. (2008) observed that 7.2 $\mathrm{Mg} \mathrm{ha}^{-1}\left(300 \mathrm{~kg} \mathrm{ha}^{-1}\right.$ of $\mathrm{N}$ ) of pelletized poultry manure incorporated into the soil at the pre-planting stage increased $(\mathrm{p}<0.05)$ by $28.4 \%\left(7.0 \mathrm{Mg} \mathrm{ha}^{-1}\right)$ the marketable tuber yield. However, if compared to the control treatment, 14.4 $\mathrm{Mg} \mathrm{ha} \mathrm{h}^{-1}\left(600 \mathrm{~kg} \mathrm{ha}^{-1}\right)$ of pelletized poultry manure did not increase $(p>0.05)$ the marketable tuber yield and also resulted in excessive $\mathrm{NO}_{3}^{-}-\mathrm{N}$ levels at harvest. Over $318 \mathrm{~mm}$ of accumulated rainfall, triticale straw mulch $\left(2.5 \mathrm{Mg} \mathrm{ha}^{-1}\right)$ resulted in less $17.6 \mathrm{~kg} \mathrm{ha}^{-1}$ of $\mathrm{NO}_{3}^{-} \mathrm{N}(\mathrm{p}<0.05)$ in the 0-0.6 m layer of a silty soil (730-760 $\mathrm{g} \mathrm{kg}^{-1}$ of silt), in relation to plots without mulching after organic potato harvest, with no differences $(p>0.05)$ in the total tuber yield among these treatments (Döring et al. 2005). Rice straw mulch (6.0 $\left.\mathrm{Mg} \mathrm{ha}^{-1}\right)$ under a $53 \mathrm{~mm}$ average rainfall regime, during two cropping seasons, improved the urea-N efficiency and, due to better hydrothermal conditions, tuber yields with $225 \mathrm{~kg} \mathrm{ha}^{-1}$ of $\mathrm{N}$ in non-mulched plots were, on average, $11.1 \%$ lower $(p<0.05)$ than with $135 \mathrm{~kg} \mathrm{ha}^{-1}$ of $\mathrm{N}$ applied in mulched plots, in two experiments (Singh et al. 2015).

The reduction of the specific gravity, as the poultry litter doses increased only on mulched plots, reinforces the argument that nutrients were more available in this treatment (Figure 4). With $30 \mathrm{Mg} \mathrm{ha}^{-1}$ of poultry litter, the specific gravity of marketable tubers over mulching was $1.4 \%$ higher $(\mathrm{p}<0.05)$ than in the non-mulched treatment. Poultry litter and fresh Elephant grass mulch, as a physical barrier, may have a negative effect on the specific gravity of marketable tubers, due to the avoidance of $\mathrm{N}$ and $\mathrm{K}$ soil leaching and excessive $\mathrm{K}$ supply in both treatments, as this soil is very rich in this nutrient. The effect of poultry manures applied at the pre-planting 


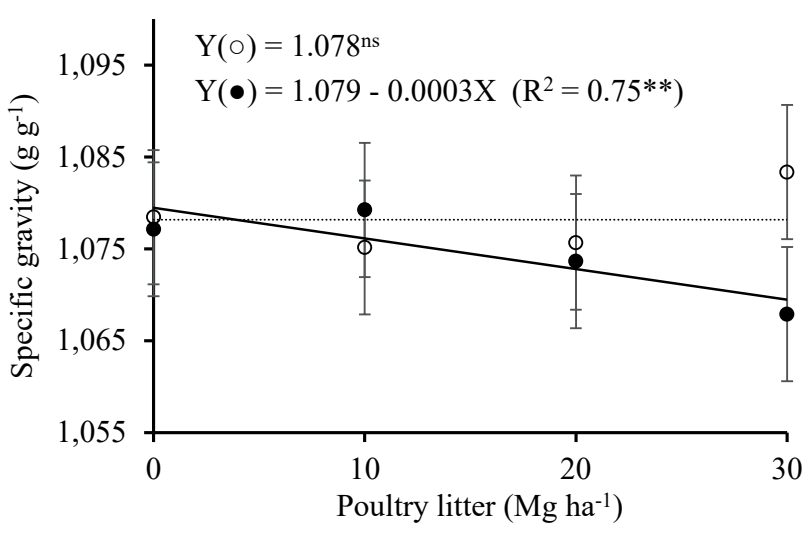

Figure 4. Specific gravity of marketable tubers (Y), as a function of treatments without $(\mathrm{O})$ or with $(\bullet)$ Elephant grass mulching combined with poultry litter doses (X) incorporated into the soil at the pre-planting stage of organic potato crop. Vertical bars are the mean standard errors. ${ }^{\text {ns }}$ and $* *$ : non-significant $(p>0.05)$ and significant $(\mathrm{p}<0.01)$ values, respectively.

stage on the tuber specific gravity of potatoes was also observed under non-mulch conditions (Lynch et al. 2008, Rees et al. 2014). Without grass mulch, the specific gravity of tubers did not decrease with the poultry litter doses, due to the leaching of cations through the soil profile, which may also have been favored by the organic fertilizer. According to Gebrim et al. (2008), inorganic anions, such as chloride, nitrate and sulfate, and low molecular weight organic acids, such as malic and oxalic acids, present in poultry litter, help as an ion pair in the leaching of $\mathrm{Ca}, \mathrm{Mg}, \mathrm{K}$ and $\mathrm{Na}$.

\section{CONCLUSIONS}

1. The incorporation of poultry litter to the soil at the pre-planting stage of potato or the use of fresh Elephant grass mulch after potato hilling reduces the late blight infestation on leaves, in the organic system;

2. The application of fresh grass mulch after the hilling operation potentiates the effect of organic fertilization at the pre-planting of potato;

3. Pre-planting poultry litter doses increase the yields and decrease the specific gravities of marketable tubers, in association with fresh grass mulch;

4. The application of poultry litter at the preplanting stage and fresh grass mulch improve the sustainable potato cultivation in the organic production system.

\section{REFERENCES}

ARORA, R.; SHARMA, S.; SINGH, B. P. Late blight disease of potato and its management. Potato Journal, v. 41, n. 1, p. 61-40, 2014.

BARBOSA, J. C.; MALDONADO JÚNIOR, W. Experimentação agronômica e AgroEstat: sistema para análises estatísticas de ensaios agronômicos. Jaboticabal: Multipress, 2015.

BERRY, P. M.; SYLVESTER-BRADLEY, R.; PHILIPPS, L.; HATCH, D. J.; CUTTLE, S. P.; RAYNS, F. W.; GOSLING, P. Is the productivity of organic farms restricted by the supply of available nitrogen? Soil and Use Management, v. 18, n. 1, p. 248-255, 2002.

CAO, W.; TIBBITTS, T. W. Study of various $\mathrm{NH}_{4}^{+} / \mathrm{NO}_{3}^{-}$ mixtures for enhancing growth of potatoes. Journal of Plant Nutrition, v. 16, n. 9, p. 1691-1704, 1993.

DÖRING, T. F.; BRANDT, M.; HEB, J.; FINCKH, M. R.; SAUKE, H. Effects of straw mulch on soil nitrate dynamics, weeds, yield, and soil erosion in organically grown potatoes. Field Crops Research, v. 94, n. 2-3, p. 238-249, 2005.

DÖRING, T. F.; HEIMBACK, U.; THIEME, T.; FINCKH, M.; SAUKE, H. Aspects of straw mulching in organic potatoes. I. Effects on microclimate, Phytophthora infestans, and Rhizoctonia solani. Nachrichtenbl Deutschland Pflanzenschutzd, v. 58, n. 3, p. 73-78, 2006.

DVORÁK, P.; TOMASEK, J.; HAMOUZ, K. Cultivation of organic potatoes with the use of mulching materials. Zeszyty Problemowe Postepow Nauk Rolniczych, v. 557, n. 1, p. 95-102, 2010.

EMPRESA BRASILEIRA DE PESQUISA AGROPECUÁRIA (Embrapa). Manual de métodos de análises de solo. 2. ed. Rio de Janeiro: Embrapa, 1997.

EMPRESA BRASILEIRA DE PESQUISA AGROPECUÁRIA (Embrapa). Sistema brasileiro de classificação de solos. 4. ed. Rio de Janeiro: Embrapa, 2014.

FINCKH, M. R.; SCHULTE-GELDERMANN, E.; BRUNS, C. Challenges to organic potato farming: disease and nutrient management. Potato Research, v. 49, n. 1, p. 27-42, 2006.

FIOREZE, C.; CERETTA, C. A. Organic sources of nutrients in potato production systems. Ciência Rural, v. 36, n. 6, p. 1788-1793, 2006.

GAO, Y.; JIA, L.; HU, B.; ALVA, A.; FAN, M. Potato stolon and tuber growth influenced by nitrogen form. Plant Production Science, v. 17, n. 2, p. 138-143, 2014.

GEBRIM, F. O.; SILVA, I. R.; NOVAIS, R. F.; VERGÜTZ, L. V.; PROCÓPIO, L. C.; NUNES, T. N.; JESUS, G. L. 
Lixiviação de cátions favorecida pela presença de ânions inorgânicos e ácidos orgânicos de baixa massa molecular em solos adubados com camas de aviário. Revista Brasileira de Ciência do Solo, v. 32, n. 6, p. 2255-2267, 2008.

ISLAM, M. R.; MONDAL, C.; HOSSAIN, I.; MEAH, M. B. Organic management: an alternative to control late blight of potato and tomato caused by Phytophthora infestans. International Journal of Theoretical \& Applied Sciences, v. 5, n. 2, p. 32-42, 2013.

JAMES, W. C. An illustrated series of assessment keys for plant diseases, their preparation and usage. Canadian Plant Disease Survey, v. 51, n. 2, p. 39-65, 1971.

KADER, M. A.; SENGE, M.; MOJID, M. A.; ITO, K. Recent advances in mulching materials and methods for modifying soil environment. Soil \& Tillage Research, v. 168, n. 1, p. 155-166, 2017.

KLEINWECHTER, U.; GASTELO, M.; RITCHIE, J.; NELSON, G.; ASSENG, S. Simulating cultivar variations in potato yields for contrasting environments. Agricultural Systems, v. 145, n. 1, p. 51-63, 2016.

LYNCH, D. H.; ZHENG, Z.; ZEBARTH, B. J.; MARTIN, R. C. Organic amendment effects on tuber yield, plant $N$ uptake and soil mineral $\mathrm{N}$ under organic potato production. Renewable Agriculture and Food System, v. 23, n. 3, p. 250-259, 2008.

NASCENTE, A. S.; CRUSCIOL, C. A. C.; STONE, L. F. Straw degradation and nitrogen release from cover crops under no-tillage. Revista Caatinga, v. 27, n. 2, p. 166175, 2014.

NAZARENO, N. R. X.; PEREIRA, A. da S.; SILVA, G. O. da; CASTRO, C. M.; BERTONCINI, O.; MEDEIROS, C. A. B.; HIRANO, E.; GOMES, C. B.; CAMPOS, J. F. IPR CRIS: cultivar rústica de batata. Horticultura Brasileira, v. 33, n. 3, p. 404-408, 2015.

NÚCLEO ESTADUAL PARANÁ-SOCIEDADE BRASILEIRA DE CIÊNCIA DO SOLO (Nepar-SBCS). Manual de adubação e calagem para o estado do Paraná. Curitiba: SBCS/Nepar, 2017.

NYANKANGA, R. O.; WIEN, H. C.; OLANYA, O. M. Effects of mulch and potato hilling on development of foliar blight (Phytophthora infestans) and the control of tuber blight infection. Potato Research, v. 51, n. 1, p. 101-111, 2008.

OSAKI, M.; SHIRAI, J.; SHINANO, T.; TADANO, T. Effects of ammonium and nitrate assimilation on the growth and tuber swelling of potato plants. Soil Science Plant and Nutrition, v. 41, n. 4, p. 709-719, 1995.

PALMER, M. W.; COOPER, J.; TÉTARD-JONES, C.; REDNICKA-TOBER, D.; BARAŃSKI, M.; SHOTTON, P. N.; VOLAKAKIS, N.; CAKMAK, C.; OZTURK, L.;
LEIFERT, C.; WILCOCKSON, S. J.; BILSBORROWA, P. E. The influence of organic and conventional fertilization and crop protection practices, preceding crop, harvest year and weather conditions on yield and quality of potato (Solanum tuberosum) in a long-term management trial. European Journal of Agronomy, v. 49, n. 1, p. 83-92, 2013.

PAVAN, M. A.; BLOCH, M. F.; ZEMPULSKI, H. C.; MIYAZAWA, M.; ZOCOLER, D. C. Manual de análise química do solo e controle de qualidade. Londrina: Iapar, 1992. (Circular técnica, 76).

REES, H. W.; CHOW, T. L.; LORO, P. J.; LAVOIE, J.; MONTHEIT, J. O.; BLAAUW, A. Hay mulching to reduce runoff and soil loss under intensive potato production in northwestern New Brunswick, Canada. Canadian Journal of Soil Science, v. 82, n. 2, p. 249-258, 2002.

REES, H. W.; CHOW, T. L.; ZEBARTH, B.; XING, Z.; LAVOIE, J.; DAIGLE, J.-L. Impact of supplemental poultry manure application on potato yield and soil properties on a loam soil in north-western New Brunswick. Canadian Journal of Soil Science, v. 94, n. 1, p. 49-65, 2014.

ROGERI, D. A.; ERNANI, R. P.; MANTOVANI, A.; LOURENÇO, K. S. Mineralização e nitrificação do nitrogênio proveniente da cama de aves aplicada ao solo. Revista Brasileira de Engenharia Agrícola e Ambiental, v. 19 , n. 6 , p. 534-540, 2015.

ROS, B.; MOHLER, V.; WENZEL, G.; THÜMMLER, F. Phytophthora infestans-triggered response of growth- and defense-related genes in potato cultivars with different levels of resistance under the influence of nitrogen availability. Physiology Plantarum, v. 133, n. 2, p. 386396, 2008.

SERIO, F.; ELIA, A.; SIGNORE, A.; SANTAMARIA, P. Influence of nitrogen form on yield and nitdose content of subirrigated early potato. Journal of Science of Food and Agriculture, v. 84, n. 11, p. 1428-1432, 2004.

SINGH, C. B.; SINGH, S.; ARORA, V. K.; SEKHON, N. K. Residue mulch effects on potato productivity and irrigation and nitrogen economy in a subtropical environment. Potato Research, v. 58, n. 3, p. 245-260, 2015.

TEDESCO, M. J.; GIANELLO, C.; BISSANI, C. A.; BOHNEN, H.; VOLKWEISS, S. J. Análise de solo, plantas e outros materiais. 2. ed. Porto Alegre: Ed. UFRGS, 1995. (Boletim técnico de solos, 5).

TIEMENS-HULSCHER, M.; VAN BUEREN, E. T. L.; STRUIK, P. C. Identifying nitrogen-efficient potato cultivars for organic farming. Euphytica, v. 199, n. 1-2, p. 137-154, 2014.

USA. Soil Survey Staff. Keys to soil taxonomy. 12. ed. Washington, DC: USDA-NRCS, 2014. 